\title{
ELABORATION OF A FIRE PREVENTION AND FIRE FIGHTING PROJECT IN THE MANAUS-AMAZONAS CITY
}

\section{Matheus Pereira da Silva ${ }^{1}$, David Barbosa de Alencar ${ }^{2}$, Davi Samuel Dias Maia ${ }^{3}$ and Igor Felipe Oliveira Bezerra ${ }^{4}$}

\author{
${ }^{1}$ Braulo Cardoso de Mattos Higher Education Institute - FASERRA. Manaus-Amazonas, Brazil. \\ ${ }^{2,3}$ Galileo Institute of Technology and Education of the Amazon - ITEGAM. Manaus-Amazonas, Brazil. \\ ${ }^{4}$ Nilton Lins University. Manaus-Amazonas, Brazil.
}

Email: matheuslv2012@gmail.com, david002870@hotmail.com, davisdm39@gmail.com, igor.bezerra@uniniltonlins.edu.br

Received: Aug $27^{\text {th }}, 2019$

Accepted: Aug 30th 2019

Published: December 02 ${ }^{\text {th }}, 2019$

Copyright (C2016 by authors and Galileo Institute of Technology and Education of the Amazon (ITEGAM).

This work is licensed under the Creative Commons Attribution International License (CC BY 4.0).

https://creativecommons.org/licen ses/by/4.0/

\begin{abstract}
There is a known shortage in the technical literature regarding fire prevention and fire fighting, which is often not even a constant subject in the curriculum of engineering courses. In Manaus, fire projects are regulated by the Fire Brigade Technical Standards, so there is often a technical deficiency in the preparation of these projects. In this context this work is inserted, aiming to provide a logical and normative roadmap for the correct design of fire prevention and fire prevention facilities. The object of study adopted is a Shed of 2,112.00 square meters, located in the West Zone of Manaus. The design determined a mixed fire fighting system between extinguishers and fire hydrants, requiring the adoption of elevated reservoir systems and fire pumps.
\end{abstract}

Keywords: Prevention, Fire, Water Pumps.

\section{Opean Acectes}

\section{INTRODUTION}

There is a close relationship between the discovery of fire, its use as a tool and the beginning of technological advances in the early Paleolithic period. Once under control, man used fire in exquisite innovations and gained the primacy and control under his surroundings to begin to develop the first great civilizations.

However, historically the use of fire has had consequences, such as the $64 \mathrm{AD}$ fire in Rome, which devastated the metropolis and the $1666 \mathrm{AD}$ fire in London. This history of major fires has led to a natural evolution in fire fighting systems.

In Brazil, it was no different, with outdated legislation behind the rest of the world, it was only after the Joelma Building fire [1] in 1975 that modern prevention techniques were developed, with prior control of projects, and supervision of normative criteria by the Fire Department, the Table below shows the history of large fires in Brazil.
Table 1: Fires in Brazil.

\begin{tabular}{|c|c|c|}
\hline \multicolumn{3}{|c|}{ Fires and Tragedies in Brazil } \\
\hline $\begin{array}{c}\text { Gran Circo Norte Americano } \\
(1961)\end{array}$ & RJ & $500{\text { dead and } 800 \text { injured }^{2}}^{2}$ \\
\hline Edificio Andraus (1972) & SP & 16 dead and 332 injured \\
\hline Edifício Joelma (1974) & SP & 179 dead and 320 injured \\
\hline Edifício Grande Avenida (1981) & SP & 17 dead and 53 injured \\
\hline Pojuca (1983) & BA & 100 dead and 200 injured \\
\hline Vila Socó (1984) & SP & 500 dead $^{2}$ \\
\hline Osasco Plaza (1996) & SP & 45 dead and 482 injured \\
\hline Boate Kiss (2013) & RS & 242 dead and 680 injured \\
\hline
\end{tabular}
Source: [2].

1. Some images in this manual were obtained from the internet. 2. Approximate or estimated values.

In fact, Brazil has an unfortunate history of fires, resulting from the negligence of engineering professionals with the necessary regulations for the approval of the Fire Department, a fact that often occurs due to ignorance of people. 
In this context, this course completion work is a means of disseminating, by practical example, the application of technical standards and analysis and design tools for firefighting installations.

\section{LITERATURE REVISION}

\section{II.1 FIRE THEORY}

Humankind incorporated fire into its routine thousands of years ago, and over time it has been establishing better ways to control and deal with it in ways that compromise its integrity less and less. However, one of the remaining challenges is full control of fire. Equipment has been developed and strategies designed to prevent the unbridled spread of the flames, but eventually they get out of control, and this episode we call Fire (Conflagration) [3].

Fire is a chemical reaction that occurs with the rapid oxidation of combustible material with air by a heat source that generates flame, releases heat, emits smoke, gases and other debris [4]. Fire can also be called combustion, which is the exothermic reaction that consists of combining combustible material with oxidizer (oxygen from the air), which initiates a chemical reaction when in contact with air [5].

A [6] conceptualizes fire as a combustion process characterized by the emission of light and heat. According to [7], fire can also be called combustion, which is an exothermic reaction, and for the phenomenon of fire to occur, there must be the simultaneous occurrence of four essential elements, which are:

- fuel; Oxidant (oxygen); Heat; Chain reaction.

Fuels are the materials susceptible to burning, that is, what will be consumed by the flames, can be solid, liquid or gaseous.

Comburent is the chemical agent that activates and conserves combustion, combining with fuel gases or vapors to form a flammable mixture. In other words, oxidizer is considered the oxygen present in atmospheric air. To maintain the occurrence of fire, the percentage of oxygen present in the environment cannot be less than $14 \%$ by volume. [2], Oxygen is the most common of oxidants, since its constant presence in the atmosphere (21\% in air) allows the burning to develop quickly and completely. However, in environments where oxygen supply is reduced or consumed during combustion a combustion depletion is observed, with less enthusiastic flames and a predominant presence of embers when the concentration is between $15 \%$ and $9 \%$ and finally with combustion termination occurring in environments where oxygen supply in the air is less than $9 \%$.

Heat is the energy that initiates, maintains and encourages the spread of fire. It is the causative agent of the chemical reaction of the flammable mixture from the combustion of fuel and oxidizer.

Chain Reaction is a heat transfer from one molecule of the combustion material to the still intact neighboring molecule, which will heat and ignite, successively, until all material is in combustion.

Combustion then is nothing more than the reaction involving these four elements, didactically represented by the fire tetrahedron:

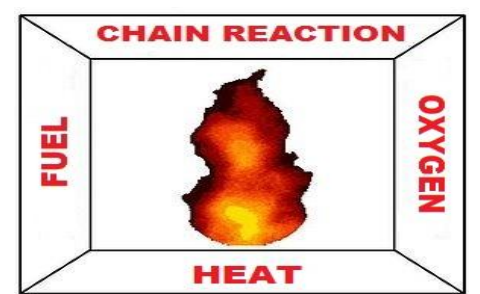

Figure 1: Fire Tetrahedron. Source: [2]

\section{II.2 FIRE THEORY (CONFLAGRATION)}

For [8] fires are classified according to combustible material, and can be described in six different classes, which are: A, B, C, D, K and I.

This classification was prepared by NFPA - National Fire Protection Association / USA, and adopted by the following institutions: IFSTA - International Fire Service Training Association/ USA: ABNT - Associação Brasileira de Normas Técnicas e Corpo de Bombeiros (Brazilian Association of Technical Standards and Fire Departments) / BR.

- Class "A": fire in solid fuels such as wood, paper, fabric, rubber, etc. These materials burn at surface and depth and, because of their volume, leave residues after combustion such as ashes and embers. The best method of extinction is cooling, mainly by the action of water, which is the most effective extinguishing agent, and by muffling, as a secondary action.

- Class "B": fire in flammable liquids and gases or solid fuels such as gasoline, oil, kerosene, liquefied petroleum gas (LPG), etc. It is characterized by leaving no residue and burning only on the exposed surface. The best extinguishing method is by muffling, by breaking the chemical chain reaction, and the best extinguishing agent for this case is the mechanical foam, and may also use dry chemical powder and gases.

- Class "C": fire in energized materials and equipment, such as motors, transformers, generators, electrical panels, etc. For extinguishing fires of this class clean agents should be used and carbon dioxide $\left(\mathrm{CO}_{2}\right)$ the best agents for this class of fire.

- Class "D": fire in combustible metals such as magnesium, selenium, antimony, lithium, potassium, fragmented aluminum, zinc, titanium, sodium and zirconium and etc. It is characterized by burning at high temperatures and reacting with common fire extinguishers agents, especially if it contains water. To extinguish this type of fire, special dry chemical powder extinguishing technique, equipment and agents are required.

- Class "K": fire involving vegetable oil and animal fat, either in solid or liquid state, with commercial or industrial kitchens as an example of environments. This class is still little known in Brazil, and for the extinguishing of this type of fire, extinguishing agents are required to provide excellent coverage in the form of a muffled sheet.

- Class "I": fire involving radioactive and chemical materials in large proportions, requiring highly trained equipment and teams. There is not enough technical literature to safeguard this fire class.

The fire presents a phase of evolution, as stated by [9], the phases of the fire can be simplified between Ascending and Descending.

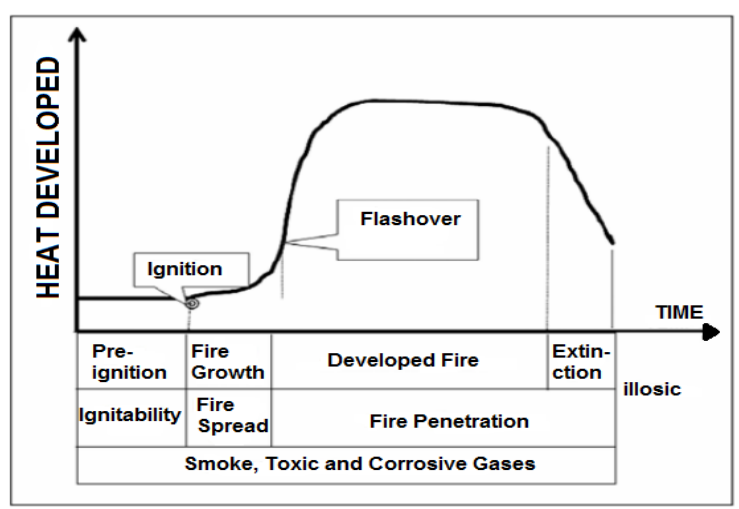

Figure 2: Fire Evolution. Source: [9]. 


\section{MATERIALS AND METHODS}

For the elaboration of this article, an evaluation was first made about the place to be dimensioned and its surroundings. After this, we sought in the technical-normative references the practical criteria to define the fire fighting techniques to be adopted.

\section{III.1 DESCRIPTION OF THE COMPANY EVALUATED}

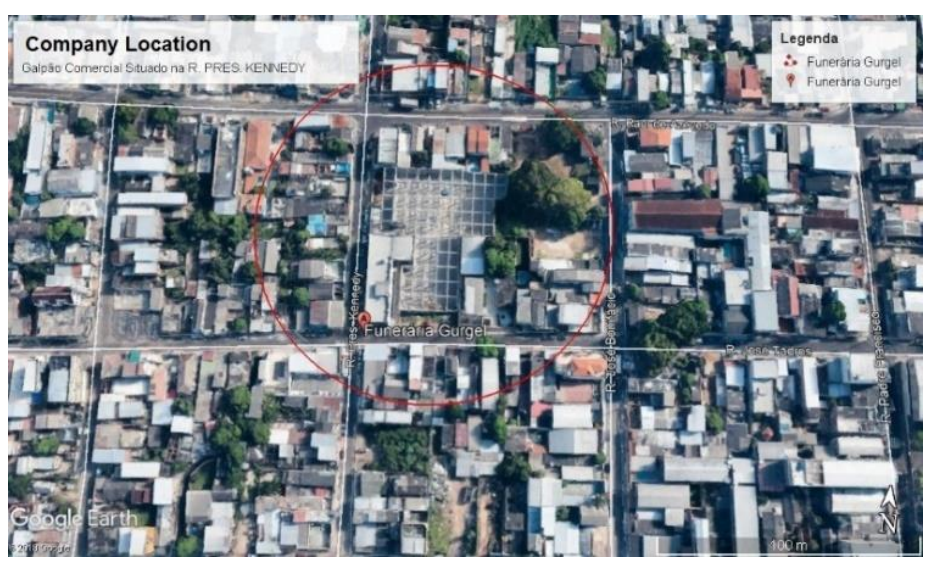

Figure 3: Company Location.

Source: Authors, (2019).

Address: José Tadros Street, Neighborhood: Santo Antônio - Manaus, AM.

Construction Type: Industrial Shed.

Total Area: 2,747.00 m²

Constructed Area: $2.112,00 \mathrm{~m}^{2}$

The venture was intended to act as a commercial deposit, of inputs brought upon importation, with medium flammability potential.

It has a medium construction standard, with galvanized roofing, structured under metal profiles, concrete block masonry walls and reinforced concrete floor.

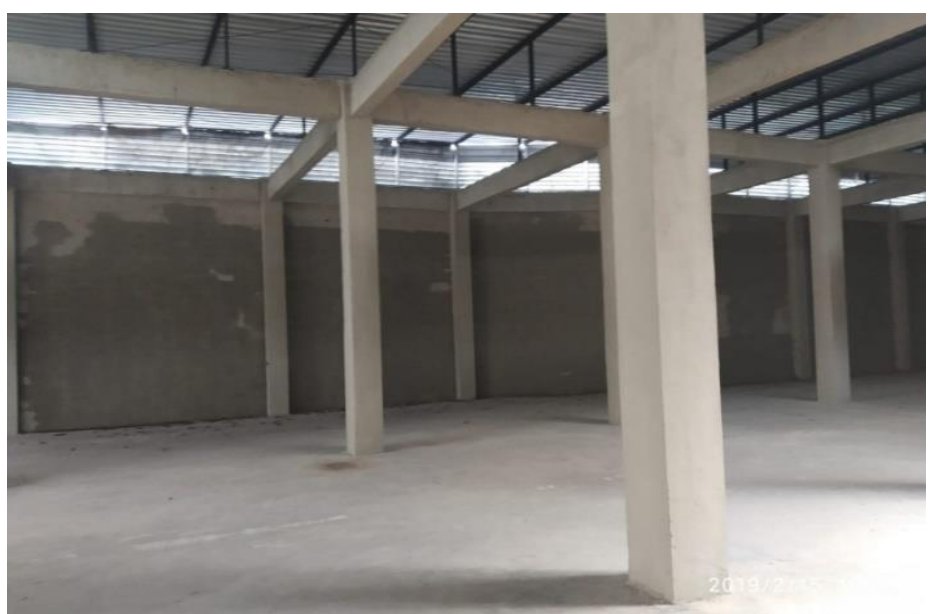

Figure 4: Company Interior. Source: Authors, (2019).

\section{RESULTS}

\section{IV.1 BUILDING FRAMEWORK}

According to the characteristics of the project, the framework will be defined, which will define specific dimensioning issues. Table below):
Table 2: Height Classification.

\begin{tabular}{|c|c|}
\hline Type & Height \\
\hline I & Ground Floor \\
\hline II & $\mathrm{H} \leq 6,00 \mathrm{~m}$ \\
\hline III & $6,00 \mathrm{~m}<\mathrm{H} \leq 12,00 \mathrm{~m}$ \\
\hline IV & $12,00 \mathrm{~m}<\mathrm{H} \leq 23,00 \mathrm{~m}$ \\
\hline $\mathrm{V}$ & $23,00 \mathrm{~m}<\mathrm{H} \leq 30,00 \mathrm{~m}$ \\
\hline VI & Above de $30,00 \mathrm{~m}$ \\
\hline
\end{tabular}

Source: [10].

Occupation: Flammable Potential Material Storage Area between $300 \mathrm{MJ} / \mathrm{M}^{2}$ to $600 \mathrm{MJ} / \mathrm{M}^{2}$.

Risk: Risk defined as Medium Risk, according to Table 3.

Table 3: Risk Rating.

\begin{tabular}{|c|c|}
\hline Risk & Fire charge MJ/m \\
\hline Low & Up to $300 \mathrm{MJ} / \mathrm{m}^{2}$ \\
\hline Medium & Between 300 snd $1.200 \mathrm{MJ} / \mathrm{m}^{2}$ \\
\hline High & Over $1.200 \mathrm{MJ} / \mathrm{m}^{2}$ \\
\hline
\end{tabular}

Protected Area: 2,112.00 $\mathrm{m}^{2}$.

According to NT 01/2014, the project falls into category J - 3.

\section{IV.2 EXTINGUISHER SIZING}

In line with current NT, the number of extinguishers has been sized so that they are located no more than 5 meters away from access doors and stairs.

Since the building is considered as Medium Risk, the extinguishers obey the spacing within a radius of 20 meters, as shown in the tables below.

Table 4: Fire Hazard Classification.

\begin{tabular}{|c|c|c|}
\hline Domain Area & Fire Hazard & $\begin{array}{l}\text { Maximum distance to } \\
\text { be traveled }\end{array}$ \\
\hline $500 \mathrm{~m}^{2}$ & Small (Class A) & $20 \mathrm{~m}$ \\
\hline $250 \mathrm{~m}^{2}$ & Medium (Class B) & $10 \mathrm{~m}$ \\
\hline $150 \mathrm{~m}^{2}$ & Large (Class C) & $10 \mathrm{~m}$ \\
\hline
\end{tabular}

Source: [11].

Table 5: Structure Risk classification.

\begin{tabular}{|c|c|}
\hline Structure fire hazard & $\begin{array}{l}\text { Distance to be } \\
\text { traveled }\end{array}$ \\
\hline Small (Class A) & $25 \mathrm{~m}$ \\
\hline Medium (Class B) & $20 \mathrm{~m}$ \\
\hline Large (Class C) & $15 \mathrm{~m}$ \\
\hline
\end{tabular}

Source: [11].

Were dimensioned for the project 18 standard ABC Fire extinguishers of $6.0 \mathrm{KG}$.

In the case of extinguishers, regarding the execution, the technical norm will be obeyed: The extinguishers must be sealed, with due pressure and have a seal of conformity granted by a body accredited by the Brazilian Certification System (Inmetro). For inspection by the Fire Department, the expiry date of the charge and the operation guarantee of the extinguishers shall be as set by the manufacturer, if new, or by the Inmetro-certified maintenance company if it is recharged. 
The extinguisher will be demarcated under the pavement with the following pattern:

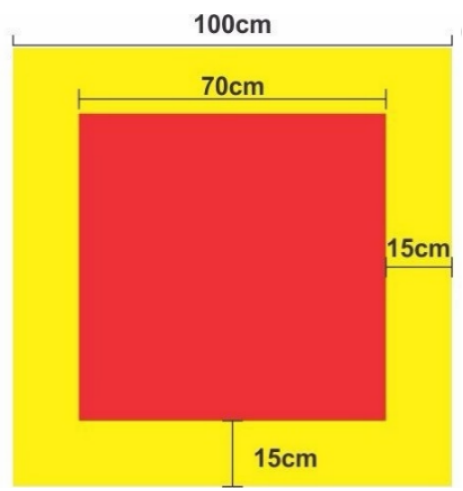

Figure 5: Fire Extinguisher Demarcation. Source: [11].

\section{IV.3 HYDRANT SIZING}

The sizing took place in accordance with the technical norms, so that criteria were obeyed:

In any building, sizing shall consist in determining the necessary and sufficient piping, diameters, fittings and supports to ensure the operation of the systems provided for in this Standard.

Fire hydrants or mangotinhos should be distributed in such a way that any point in the area to be protected is reached by one (type 1 system) or two (type 2 and 3 systems) nozzles, considering the length of the hose (s) and its actual path and disregarding the range of the water jet.

For sizing, it should be considered the simultaneous use of the two water jets most unfavorable hydraulically, for any type of system specified, considering at least the flows obtained according to table 1 and conditions.

The system must be dimensioned so that the dynamic pressures on the inputs of the squirts do not exceed twice that obtained in the most unfavorable squirt hydraulically. You can use any pressure reduction devices, provided that you have proven your technical adjustments.

It is recommended that the system be dimensioned so that the maximum working pressure, at any point in the system, does not exceed $1000 \mathrm{kPa}$. Situations that require pressures exceeding the stipulated will be accepted, provided that the technical adequacy of the components employed and fulfilled the requirement specified in.

The hydraulic calculation of the pipes must be performed by methods suitable for this purpose, and the results achieved must satisfy one of the following equations:

$$
\mathrm{h}_{\mathrm{f}}=f \cdot \frac{L \cdot v^{2}}{D \cdot 2 \cdot g}
$$

Figure 6: A) Colebrook ("universal formula"). Source: [12].

Where: hf is the load loss, in meters of water column; $\mathrm{f}$ is the friction factor; $\mathrm{L}$ is the virtual length of the pipe (pipes + fittings), in meters; $\mathrm{D}$ is the inner diameter, in meters; $\mathrm{v}$ is the velocity of the fluid, in meters per second; $g$ is the acceleration of gravity, in meters per second, per second;

\section{$J=605 \times Q^{1,85} \times C^{-1,85} \times D^{-4,87} \times 10^{4}$}

Figure 7: B) Hazen Williams.

Source: [12].

Where: $\mathrm{J}$ is the loss of friction load, in kilopascals per metre; $\mathrm{Q}$ is the flow rate, in liters per minute; $\mathrm{C}$ is the factor of Hazen Williams (see table 3); D is the inner diameter of the tube, in millimeters.

The water velocity in the suction tube of the fire pumps should not be more than $5 \mathrm{~m} / \mathrm{s}$, which should be calculated by the equation: A Q V =; For the area should be considered the internal diameter of the pipe where: $\mathrm{V}$ is the water velocity, in meters per second; $\mathrm{Q}$ is the water flow, in cubic meters per second; $\mathrm{A}$ is the inner area of the pipe, in square meters.

The maximum water speed in the pipe shall not exceed 5 $\mathrm{m} / \mathrm{s}$, which shall be calculated according to the equation indicated; The calculation of the load loss factor occurs according to the option of the material and the query to the table:

Table 6: Roughness factor.

\begin{tabular}{|l|c|}
\hline \multicolumn{1}{|c|}{ Tube type } & Factor "C " \\
\hline Cast iron or ductile without internal coating & 100 \\
\hline Black steel (dry tube system) & 100 \\
\hline Black steel (wet tube system) & 120 \\
\hline Galvanized & 120 \\
\hline Plastic & 150 \\
\hline $\begin{array}{l}\text { Cast iron or ductile without internal cement } \\
\text { coating }\end{array}$ & 140 \\
\hline Copper & 150 \\
\hline
\end{tabular}

Source: [13].

\section{IV.4 HYDRANT POSITIONING}

The water outlets must be positioned:

(a) in the vicinity of external doors and/or accesses to the area to be protected, not more than $5 \mathrm{~m}$;

(b) in central positions in protected areas;

(c) outside of the stairs or smoke antechambers;

(d) from $1.0 \mathrm{~m}$ to $1.5 \mathrm{~m}$ from the floor.

In external hydrants, when they are removed at least $15 \mathrm{~m}$ or 1.5 times the height of the external wall of the building to be protected, can be used up to $60 \mathrm{~m}$ of hose (preferably in bids of 15 $\mathrm{m}$ ), provided that properly dimensioned hydraulically. It is recommended to use $65 \mathrm{~mm}$ diameter hoses to reduce the system load loss and the last bid of $40 \mathrm{~mm}$ to facilitate handling.

The use of the system should not compromise the escape of the occupants of the building; Therefore, it must be designed in such a way that it gives protection throughout the building, without the need to enter the stairs, antechambers or other places determined exclusively to serve as an escape route for the occupants.

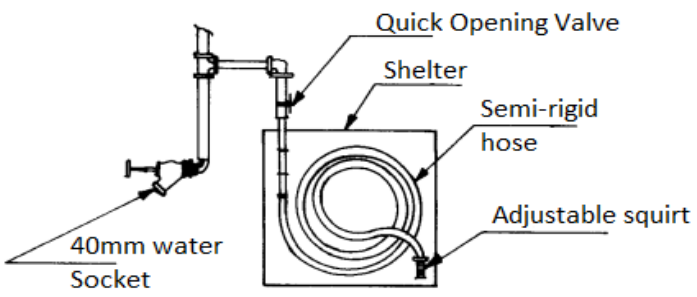

Figure 8: System model. Source: [13]. 
All hydrant or mangotinhos points must be signalling according to NBR 13435, in order to allow their quick location.

\section{IV.5 RESERVOIR SIZING}

According to [4] the reservoirs can be classified as upper or lower and the volume is defined by the flow of the type of hydrant indicated by the 13714/2011 standard and the operating time which is 1 hours for types 1 and 2:30 hour for type 3. For type 2 hydrants with a flow rate of 3001/min The Minimum Fire Technical Reserve (RTI) should be 360001 . It is important to emphasize that the standard determines the simultaneous use of at least two hydrants and that the minimum flow rate should meet the hydrants or mangotinhos less Favorable, those with lower pressure.

According to [12] of the São Paulo Fire Department, one can admit to the undertaking a fire technical reserve of 12,000 liters.

Table 7 - Reservoir Sizing.

\begin{tabular}{|c|c|c|c|c|c|}
\hline \multirow[b]{2}{*}{$\begin{array}{l}\text { AREAS OF } \\
\text { BUILDINGS } \\
\text { AND AREAS } \\
\text { OF RISK }\end{array}$} & \multicolumn{5}{|c|}{ CLASSIFICATION OF BUILDINGS AND AREAS OF RISK } \\
\hline & $\begin{array}{r}\text { A } \\
\text { D-1 e D-3 } \\
D \\
E-1 \\
E-4 \\
F-1 \text { (up } \\
F-2, F \\
G-1, G \\
H 1, H-2, \\
\text { J }\end{array}$ & $\begin{array}{l}\text { A-3; } \\
1 ; \\
\left.\text {;o } 300 \mathrm{MJ} / \mathrm{m}^{2}\right) \text {; } \\
\text { D-4; } \\
\text { 2, E-3, } \\
\text { 5, E-6; } \\
\text { O MJ/m²); } \\
\text { F-4, F-8; } \\
\text { G-3, G-4; } \\
\text { 3, H-5, H-6; } \\
\text { 1; } \\
\text { J-2; } \\
-3 .\end{array}$ & $\begin{array}{c}\text { B-1, B-2; } \\
\text { C-2( above } 300 \text { ate } 1000 \\
\text { MJ/m²); } \\
\text { C-3; } \\
\left.\text { D-1( above } 300 \mathrm{MJ} / \mathrm{m}^{2}\right) ; \\
\left.\text { D-3( above } 300 \mathrm{MJ} / \mathrm{m}^{2}\right) ; \\
\left.\text { F-1( above } 300 \mathrm{MJ} / \mathrm{m}^{2}\right) ; \\
\text { F-5, F-6, F-7, F-9, F-10; } \\
\text { H-4; } \\
\text { I-2 }(\text { above } 300 \text { up to } 800 \\
\left.\mathrm{MJ} / \mathrm{m}^{2}\right) ; \\
\text { J-3 }(\text { above } 300 \text { up to } 800 \\
\left.\mathrm{MJ} / \mathrm{m}^{2}\right) \text {. }\end{array}$ & 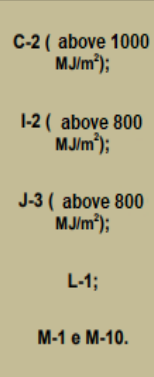 & $\begin{array}{c}\text { G-5, G-6; } \\
\text { I-3; } \\
\text { J-4; } \\
\text { L-2 e L-3. }\end{array}$ \\
\hline Above $2500 \mathrm{~m}^{2}$ & $\begin{array}{l}\text { Type } 1 \\
\text { RTI } 5 \mathrm{~m}^{3} \\
\end{array}$ & $\begin{array}{l}\text { Type } 2 \\
\text { RTI } 8 \mathrm{~m}^{3}\end{array}$ & $\begin{array}{l}\text { Tvpe } 3 \\
\text { RTI } 12 \mathrm{~m}^{3} \\
\end{array}$ & $\begin{array}{c}\text { Tvpe } 4 \\
\text { RTI } 28 \mathrm{~m}^{3} \\
\end{array}$ & $\begin{array}{c}\text { Tvpe } 4 \\
\text { RTI } 32 \mathrm{~m}^{3} \\
\end{array}$ \\
\hline $\begin{array}{l}\text { Above } 2500 \mathrm{~m}^{2} \text { up } \\
\text { to } 5000 \mathrm{~m}^{2}\end{array}$ & $\begin{array}{l}\text { TVpe } 1 \\
\text { RTI } 8 \mathrm{~m}^{3}\end{array}$ & $\begin{array}{l}\text { TVpe } 2 \\
\text { RTI } 12 \mathrm{~m}^{3}\end{array}$ & $\begin{array}{l}\text { Tvpe } 3 \\
\text { RTI } 18 \mathrm{~m}^{3}\end{array}$ & $\begin{array}{l}\text { Tvpe } 4 \\
\text { RTI } 32 \mathrm{~m}^{3}\end{array}$ & $\begin{array}{c}\text { Tvpe } 4 \\
\text { RTI } 48 \mathrm{~m}^{3}\end{array}$ \\
\hline $\begin{array}{l}\text { Above } 5000 \mathrm{~m}^{2} \text { up } \\
\text { to } 10000 \mathrm{~m}^{2}\end{array}$ & $\begin{array}{c}\text { Tvpe } 1 \\
\text { RTI } 12 \mathrm{~m}^{3}\end{array}$ & $\begin{array}{l}\text { Type } 2 \\
\text { RTI } 18 \mathrm{~m}^{3}\end{array}$ & $\begin{array}{l}\text { Tvpe } 3 \\
\text { RTI } 25 \mathrm{~m}^{3}\end{array}$ & $\begin{array}{l}\text { Tvpe } 4 \\
\text { RTI } 48 \mathrm{~m}^{3}\end{array}$ & $\begin{array}{c}\text { Tvpe } 5 \\
\text { RTI } 64 \mathrm{~m}^{3}\end{array}$ \\
\hline $\begin{array}{l}\text { Above } 10000 \mathrm{~m}^{2} \\
\text { up to } 20000 \mathrm{~m}^{2}\end{array}$ & $\begin{array}{l}\text { TVpe } 1 \\
\text { RTI } 18 \mathrm{~m}^{3}\end{array}$ & $\begin{array}{l}\text { Tvpe } 2 \\
\text { RTI } 25 \mathrm{~m}^{3}\end{array}$ & $\begin{array}{l}\text { TVpe } 3 \\
\text { RTI } 35 \mathrm{~m}^{3}\end{array}$ & $\begin{array}{l}\text { Tvpe } 4 \\
\text { RTI } 64 \mathrm{~m}^{3}\end{array}$ & $\begin{array}{c}\text { Tvpe } 5 \\
\text { RTI } 96 \mathrm{~m}^{3}\end{array}$ \\
\hline $\begin{array}{l}\text { Above } 20000 \mathrm{~m}^{2} \\
\text { up to } 50000 \mathrm{~m}^{2}\end{array}$ & $\begin{array}{l}\text { Tvpe } 1 \\
\text { RTI } 25 \mathrm{~m}^{3}\end{array}$ & $\begin{array}{l}\text { Tvpe } 2 \\
\text { RTI } 35 \mathrm{~m}^{3}\end{array}$ & $\begin{array}{c}\text { Tvpe } 3 \\
\text { RTI } 48 \mathrm{~m}^{3}\end{array}$ & $\begin{array}{c}\text { Type } 4 \\
\text { RTI } 96 \mathrm{~m}^{3}\end{array}$ & $\begin{array}{c}\text { Tvpe } 5 \\
\text { RTI } 120 \mathrm{~m}^{3}\end{array}$ \\
\hline Above $50000 \mathrm{~m}^{2}$ & $\begin{array}{c}\text { Tvpe } 1 \\
\text { RTI } 35 \mathrm{~m}^{3} \\
\end{array}$ & $\begin{array}{l}\text { Type } 2 \\
\text { RTI } 48 \mathrm{~m}^{3}\end{array}$ & $\begin{array}{c}\text { TVpe } 3 \\
\text { RTI } 70 \mathrm{~m}^{3}\end{array}$ & $\begin{array}{c}\text { Type } 4 \\
\text { RTI } 120 \mathrm{~m}^{3}\end{array}$ & $\begin{array}{c}\text { Tvpe } 5 \\
\text { RTI } 180 \mathrm{~m}^{3} \\
\end{array}$ \\
\hline
\end{tabular}

\section{IV.6 SIZING PIPES}

The sizing of pipelines was made by tracing and calculating the lengths and differences of quota, and applications of the distributed load loss, inserting the values in the table below:

Table 8: Conductos dimensioning.

\begin{tabular}{|c|c|c|c|c|c|c|c|c|c|c|}
\hline \multirow{2}{*}{ Stretch } & \multirow{2}{*}{$\begin{array}{l}\text { Flow } \\
\text { Ipm }\end{array}$} & \multirow{2}{*}{$\begin{array}{l}\text { P Valve } \\
\text { Mca }\end{array}$} & \multicolumn{5}{|c|}{ Load loss (piping) } & \multirow{2}{*}{$\begin{array}{c}\text { Elevation } \\
\mathrm{m}\end{array}$} & \multirow{2}{*}{$\begin{array}{c}V \\
(\mathrm{~m} / \mathrm{s})\end{array}$} & \multirow{2}{*}{$\begin{array}{c}P_{\text {amount }} \\
\text { mca }\end{array}$} \\
\hline & & & $\mathrm{D}(\mathrm{mm})$ & $L_{\text {red }}$ & $L_{\text {vithal }}$ & $L_{\text {bital }}$ & $J_{\text {wot }} J_{\text {tital }}$ & & & \\
\hline$\overline{\mathrm{BI}-\mathrm{HA}}$ & 200,0 & 40,01 & 65 & 34,20 & 11,50 & 45,70 & $0,032 \quad 1,48$ & 0,60 & 1,005 & 42,09 \\
\hline $\mathrm{BI}-\mathrm{HB}$ & 200,0 & 42,09 & 65 & 120,87 & 7,20 & 128,07 & $0,032 \quad 4,14$ & 0,60 & 1,005 & 46,83 \\
\hline BI-RI & 400,0 & 46,83 & 65 & 4,95 & 5,20 & 10,15 & $0,117 \quad 1,18$ & 0,00 & 2,009 & 48,01 \\
\hline
\end{tabular}

Table 9: Fire Pump Sizing.

\begin{tabular}{|c|c|c|c|}
\hline \multicolumn{4}{|c|}{ Fire Pump and RTI } \\
\hline$H_{\text {man }}=48 \mathrm{mca}$ & & Fire Technical Reserve & \\
\hline $\begin{aligned} \text { Flow } & =400 \mathrm{~V} / \mathrm{min} \\
\text { Pot } & =9,5 \mathrm{cV}\end{aligned}$ & $\left.\left(24,0 \mathrm{~m}^{\mathrm{s}} / \mathrm{h}\right)\right)($ & $\begin{array}{l}\text { High } \\
\text { Underground } \\
\text { Ground level }\end{array}$ & Volume: $12 \mathrm{~m}^{3}$ \\
\hline
\end{tabular}

Source: Authors, (2019).

\section{FINAL CONSIDERATIONS}

As demonstrated, there is a logical sequence for sizing, where normative criteria often merge into different technical norms, treating each fire-fighting device differently, which may cause some difficulty the designer at the time of dimensioning.

Within the scope and initial premise, a step-by-step was elaborated, collecting didactic and expository tables along different technical norms, between NBRs, NT's and memorials, in order to expose a clear relationship between that required by law and what options Available to the designer.

For the analyzed undertaking, a system with the use of a hydrant was defined, with a technical reserve of 12,000 liters and a fire pump of $9.5 \mathrm{CV}$, with the hand of spreadsheets to assist with the various calculations preposed by NBR 13,475, in order to facilitate the Sizing process.

Finally, the work concludes a normative roadmap that can help other designers in the analysis and sizing of prevention and fire-fighting projects, in order to disseminate the technical knowledge and collaborate with the current literature in this area.

\section{REFERENCES}

[1] Viestel, Roberto Marin. Edifício Joelma: Desafios Da Oralidade.

[2] Corpo de Bombeiros Militar do Estado de Goiás. Fundamentos do Combate a Incêndio. CBM/GO. Goiânia, 2017.

[3] Pinto, Edna Moura; Calil Júnior, C. Estudo teórico e experimental sobre a degradação térmica e os gradientes térmicos da madeira de Eucalyptus de uso estrutural exposta ao fogo. Revista Minerva, 2006, 3.2: 131-140.

[4] Schenkel, Pablo Rosa. Sistema de combate a incêndio para complexos industriais - classificação e dimensionamento de hidrantes. Universidade Regional do Noroeste do Estado do Rio Grande do Sul. Rio Grande do Sul, 2017.

[5] Brentano, Telmo. A Proteção Contra Incêndio no Projeto de Edificações. 2.ed. Porto Alegre, 2010. 632p.

[6] Associação Brasileira De Normas Técnicas. ABNT NBR 13860:1997. Glossário de termos relacionados com a segurança contra incêndio. Rio de janeiro, 1997.

[7] Brentano, Telmo. Instalações Hidráulicas de Combate a Incêndio nas Edificações. 4.ed. Porto Alegre, 2011. 669p.

[8] Teixeira, Gonçalo Gomes. Sistemas de automação e manutenção de edifícios: concepção dos sistemas de detecção e protecção contra incêndios de uma unidade industrial. 2013. PhD Thesis. Instituto Superior de Engenharia de Lisboa.

[9] Seito, Alexandre Itiu, et al. A Segurança Contra Incêndio no Brasil. São Paulo: Projeto Editora, 2008. 496 p.

[10] Lei Complementar No 14.376, De 26 de Dezembro de 2013. Available in: < http://leisestaduais.com.br/rs/lei-complementar-n14376-2013-rio-grande-do-sul-estabelece-normas-sobreseguranca-prevencao-e-protecao-contra-incendios-nasedificacoes-e-areas-de-risco-de-incendio-no-estado-do-riogrande-do-sul-e-da-outras-providencias $>$. 
[11] NR 23 - Proteção Contra Incêndios. 2011. Available in: <http://www.guiatrabalhista.com.br/guia/nr23.htm>.

[12] Norma Técnica 22/2014. 2014. Available in: < https://www.bombeiros.go.gov.br/wp-

content/uploads/2014/10/nt-22_2014-sistemas-de-hidrantes-e-demangotinhos-para-combate-a-incendio.pdf $>$.

[13] Associação Brasileira De Normas Técnicas NBR 13714.

Sistemas de hidrantes e de mangotinhos para combate a incêndio.

Rio de Janeiro, 2011 Revisão. 